\title{
Hepatitis C Prevalence in Different Age Groups; People Over 50 Years of Age May Receive One-Time Testing for Anti-HCV
}

\author{
Farklı Yaș Gruplarında Hepatit C Sıklığı; Elli Yaș Üstü Bireyler Anti-HCV Yönünden Bir
} Kez Taranabilir

\author{
Özlem AYDEMIR1, Tayfur DEMIRAY1, Mehmet KÖROĞLU2, İhsan Hakkı ÇIFTÇl2, Ahmet ÖZBEK2, \\ Mustafa ALTINDIŞ2
}

${ }^{1}$ Sakarya University Training and Research Hospital, Clinical Microbiology Laboratory, Sakarya, Turkey

${ }^{2}$ Sakarya University faculty of Medicine Department of Clinical Microbiology, Sakarya, Turkey

\begin{abstract}
Objective: The aim of this study was to determine seroprevalence of hepatitis $\mathrm{C}$ virus $(\mathrm{HCV})$ in different age groups in Sakarya province. In this regard, we also aimed to contribute roughly to HCV profile of Turkey, and to determine whether there was a need for anti-HCV testing in different age groups in terms of of public health.

Materials and Methods: We retrospectively evaluated the results of anti-HCV test in 97525 patients who attended our hospital between October 2009 and February 2014. Anti-HCV antibodies in serum samples were analyzed with chemiluminescence microparticle immunoassay (CMI) method (Architect i2000, Abbott).

Results: Overall anti-HCV seropositivity was determined as $1.12 \%$ in this study. Anti-HCV positivity according to 0-9, 10-19, 20-29, $30-39,40-49$ and 50 and over age groups was found to be $0.3 \%$, $0.3 \%, 0.4 \%, 0.4 \%$ and $2.1 \%$ of $0.8 \%$, respectively. Highest positivity was $2.1 \%$ detected in 50 years and over age group. There was a significant correlation between anti-HCV seropositivity and increasing age $(p=0.020)$

Conclusion: This study showed that anti-HCV seroprevalence increased with advancing age. Based on the results of this study, since there is possibility of risky transfusions made before the era of routine screening tests before transfusion, and risk of viral transmission at procedures without aseptic conditions, onetime anti-HCV testing may be offered for screening purposes in individuals over the age of 50 years.
\end{abstract}

Key Words: Hepatitis C virus infection, anti-HCV, HCV seroprevalence, age-specific anti-HCV
ÖZET

Amaç: Bu çalışmanın amacı, Sakarya ilinde farklı yaş gruplarında hepatit $\mathrm{C}$ virüsü (HCV) enfeksiyonu sıklığını belirlemek ve ülkemiz epidemiyolojik verilerine katkıda bulunmanın yanı sıra, toplum sağlığı açısından taranması gereken yaş grupları için önerilerde bulunmaktır. Gereç ve Yöntemler: Ekim 2009 ile Şubat 2014 tarihleri arasında çeşitli nedenlerle hastanemize başvuran ve anti-HCV çalışılması için mikrobiyoloji laboratuvarına serum örneği gönderilen 97525 hastanın sonuçları değerlendirilmiştir. Serum örneklerindeki anti-HCV antikorlarının varlığı kemiluminesens mikropartikul immunoassay (CMIA) yöntemi ile (Architect i2000, Abbott) araştııımıştır.

Bulgular: Bu çalışmada, anti-HCV seroprevalansı tüm yaş gruplarında \%1,12 olarak saptanmıştır. Anti-HCV pozitifliği 0-9, 10-19, 20-29, $30-39,40-49$ ve 50 yaş üstü grupları için sırasıyla; \%0,3, \%0,3, $\% 0,4, \% 0,4, \% 0,8$ ve \%2,1 oranında bulunmuştur. Anti-HCV seroprevelansı ile artan yaş arasında anlamlı korelasyon saptanmıştır $(p=0,02)$. Yaş grupları arasında en yüksek anti-HCV seropozitifliği 50 yaş üzeri grupta tespit edilmiştir.

Sonuç: Bu çalışma, artan yaş ile birlikte anti-HCV seroprevelansının da arttığını ortaya koymuştur. Elde edilen sonuçlar doğrultusunda, kan transfüzyonu öncesinde yapılan rutin tarama testlerinin kullanıma girmediği dönemde riskli kan transfüzyonu yapıımış olma intimali ve aseptik koşullarda yapılmayan girişimlerde viral bulaş riskine karşı, 50 yaş üstü bireylerde tarama amaçlı en az bir kez anti-HCV testinin yapılması önerilebilir.

Anahtar Kelimeler: Hepatitis C virüs enfeksiyonu, anti-HCV, HCV seroprevalans, yaş gruplarında anti-HCV 


\section{Introduction}

Hepatitis C virus (HCV) infection affects large populations in Turkey as well as all over the world and continues to be a major public health problem. Determining the reliable $\mathrm{HCV}$ seroprevalance in general population is important in terms of public health and treatment policies (1). The global seroprevalence of anti-HCV is estimated at 1.3-2.1\% (2). The reports concerning hepatitis $\mathrm{C}$ epidemiology are often based on studies held on blood donors. Blood donors, however, are selected population due to donor selection criteria. Therefore, HCV seropositivity determined in blood donors is lower than general population, thus, does not reflect the data of whole country. Anti-HCV seroprevalence is given for healthy blood donors as $0.03-0.3 \%$, whereas it is reported for the whole population as $0.5-2.1 \%(1,2,3,4)$.

Antibody to $\mathrm{HCV}$ (anti-HCV) is a commonly used marker to determine HCV infection. HCV testing has been recommended since 1998 in those at highest risk for the disease, including injection drug users, people who have undergone hemodialysis, those who have received transfusions, organ transplants, or clotting factors (before 1987), and health care personnel who have been exposed to HCV-positive blood from circumstances such as needle sticks. Recently, the Centers for Disease Control (CDC) and Prevention have added a new group to that list: Every American adult born between 1945 and 1965 should take the test, since the prevalence of anti-HCV among persons born during these years is $3.25 \%$, five times higher than among adults born in other years (5).

In this study, we aimed to retrospectively investigate the HCV seropositivity in patients of different age groups admitted to our hospital and to assess whether there was a need for testing anti$\mathrm{HCV}$ in different age groups, especially in people over 50 years of age, in terms of public health.

\section{Materials and Methods}

This study was conducted in Sakarya University Training and Research Hospital from October 2009 to February 2014. Anti-HCV test results of 97525 patients were evaluated retrospectively. These patients were tested for HCV infection for diagnostic and treatment purposes as well as screening purposes such as health reports, marriage testing, and pre-operation/invasive process testing. Any repeated anti-HCV tests were excluded from the study. Tests were done with chemiluminescence micro particulate immunoassay (CMI), Architect 12000, Abbott) according to the manufacturer's recommendations. Test values, with s/co levels of greater than
1.1 were accepted as positive anti-HCV. Statistical analyses were performed using Medcalc ${ }^{\circledR} 13.0$ (MedCalc Software, Ostend, Belgium).

\section{Results}

Anti-HCV seropositivity was determined as $1.12 \%$ in whole population included in the study. Anti-HCV seropositivity was increased significantly as the age advanced $(p=0.02)$. When the age groups were evaluated, the highest positivity was $2.1 \%$ detected in 50 years and over age group (Table 1). One-way ANOVA [Post Hoc (Tukey)] test was used to determine the statistical correlation between the age groups and the anti-HCV seropositivity. Except for the 40-49 age group; significant differences were observed between all age groups.

\section{Discussion}

There are regional variations in HCV prevalence as the following: Central and East Asia and North Africa/Middle East are high prevalence regions (>3.5\%) in terms of anti-HCV positivity whereas Central, Eastern, and Western Europe have moderate prevalence rates $(1.5-3.5 \%)$ (6). Since Turkey is a country neighboring the Central/Eastern Europe and North Africa/Middle East, the prevalence rates are similar between these regions. In our country, anti-HCV prevalence in the general population is between $0.5 \%$ and $2.1 \%(2,4)$. According to the geographic regions, the prevalence rates vary between the lowest being $0.1 \%$ in Aegean Region and the highest being $0.8 \%$ in Southeast and Mediterranean Regions in Turkey. This study was conducted in Sakarya providence in Marmara Region; the rate is given as $0.5 \%$ for this region (4). The overall anti-HCV seroprevalence in this study was determined to be $1.1 \%$ in patients admitted to our hospital. Different rates varying between $0.38 \%$ and $2.1 \%$ have been found in similar studies in our region (4).

According to data from the World Health Organization (WHO), most European countries report HCV prevalence at $0.5-2 \%$ in the general population. The seropositivity of anti-HCV among injection drug users and hemophiliacs has been reported as high as $>70 \%$. Intermediate prevalence of $20 \%$ to $30 \%$ have been observed in patients receiving haemodialysis. Since universal precautions in medical settings are followed and transmission by blood products has been reduced to almost zero, the HCV infection incidence is declining (7). Mohd et al. (6) have determined antiHCV seroprevalence for Central Europe, Eastern Europe, Western

\begin{tabular}{|c|c|c|c|c|c|c|}
\hline \multirow{2}{*}{ Age Group } & \multicolumn{2}{|c|}{ Anti HCV (+) } & \multicolumn{2}{|c|}{ Anti HCV (-) } & \multirow{2}{*}{ Total } & \multirow{2}{*}{$p$ value* } \\
\hline & n & $\%$ & n & $\%$ & & \\
\hline $40-49$ & 106 & 0.8 & 13723 & 99.2 & 13829 & \multirow{4}{*}{0.02} \\
\hline $30-39$ & 80 & 0.4 & 17939 & 99.6 & 18019 & \\
\hline $10-19$ & 21 & 0.3 & 7493 & 99.7 & 7514 & \\
\hline $0-9$ & 10 & 0.3 & 2923 & 99.7 & 2933 & \\
\hline
\end{tabular}

*One-Way ANOVA tests were used to assess correlations between anti-HCV positivity and the age groups HCV: Hepatitis C virus 
Europe, North Africa/Middle East and worldwide in 2013 as $2.4 \%$, $2.9 \%, 2.4 \%$, and $2.8 \%$, respectively. In their study in 2014, Gower et al. (2) have given the anti-HCV seroprevalence for Central Europe, Eastern Europe, Western Europe, North Africa/Middle East and worldwide as $1.3 \%, 3.3 \%, 2.9 \%, 0.9 \%$, and $1.6 \%$, respectively.

$\mathrm{HCV}$ infection occurs in all age groups. It has been determined in this study and various studies conducted in Turkey that anti-HCV prevalence increases as the age advances (Table 2). Especially, after the age of 30, its prevalence increases and it is most commonly observed after the age of 50 (8). Similarly, in a study conducted in the general population in Turkey, it has been observed that anti$\mathrm{HCV}$ antibodies positivity has increased proportionally and it has reached $1.3 \%$ in age $50-59$, and it was the most prevalent with $2.4 \%$ in age 70 and over (9). Chronic hepatitis and cirrhosis have been reported to be most commonly observed in 50-59 age group (10). Kandemir et al. (11) have indicated that anti-HCV positivity rate increased with age; most commonly identified in individuals aged 65 years and over. In addition, Yıldırım et al. (12) stated that the highest positivity rate was identified in those aged 60 years and over. In a similar multicenter study conducted by Altındiş et al. (5), the rates were $0.39 \%$ and $1.35 \%$ for $18-49$, and 50 years and over age groups, respectively. In the cities Afyon, Ordu and Sakarya, a higher HCV positivity in individuals of advanced age than in other regions has also been reported. According to another study, people over 50 years of age constituted $54.23 \%$ of the antiHCV-seropositive individuals (13). In this study, we determined that, anti-HCV positivity increased with age, and we found the highest positivity rate in the 50 years and over age group as $2.1 \%$. The Centers for Disease Control and Prevention (CDC) reported that people born from 1945-1965 are five times more likely to have hepatitis C. CDC recommends that those people should take screening test for anti-HCV (14). Testing for anti-HCV became mandatory in our country by law in blood donors since 1996. One possible cause of increased anti-HCV prevalence in older age

\begin{tabular}{|c|c|c|c|c|}
\hline Study/Year & Province/City & Ages & Number & Anti-HCV Seropositivity (\%) \\
\hline Demiraslan, 2008, (15) & Adıyaman & $9-13$ & 723 & 0.0 \\
\hline Kaçmaz, 2003, (17) & Ankara & $\begin{array}{l}20-29 \\
30-39 \\
40-49 \\
50-59 \\
60-69 \\
70+ \\
\text { Total }\end{array}$ & $\begin{array}{l}252 \\
941 \\
1525 \\
902 \\
452 \\
124 \\
4196\end{array}$ & $\begin{array}{l}0.0 \\
0.3 \\
0.3 \\
0.4 \\
1.6 \\
0.0 \\
0.5\end{array}$ \\
\hline Ceylan, 2002, (18) & Diyarbakır & $\begin{array}{l}0-6 \\
7-14\end{array}$ & $\begin{array}{l}360 \\
480\end{array}$ & $\begin{array}{l}0.56 \\
0.62\end{array}$ \\
\hline Yarar, 2005, (19) & Eskişehir & Before pediatric transfusion & 19 & 0.0 \\
\hline Tekerekoğlu, 2004, (22) & Malatya & 18-45 female & 1000 & 1.3 \\
\hline Çetinkol, 2012, (23) & Ordu & $15-17$ & 200 & 0.0 \\
\hline Günal, 2010, (24) & Tokat & $0-15$ & 371 & 0.0 \\
\hline Yıldırım, 2014, (12) & Düzce & $\begin{array}{l}18-29 \\
30-39 \\
40-49 \\
50-59 \\
60+ \\
\text { Total }\end{array}$ & $\begin{array}{l}- \\
- \\
- \\
- \\
- \\
1321\end{array}$ & $\begin{array}{l}0.8 \\
0.6 \\
0.4 \\
0.5 \\
1.0 \\
0.7\end{array}$ \\
\hline Gürbüz, 2010, (25) & All Turkey & $\begin{array}{l}\text { Public screening } \\
0-9 \\
60-69 \\
\text { South-East Anatolia }\end{array}$ & $\begin{array}{l}41.006 \\
- \\
- \\
-\end{array}$ & $\begin{array}{l}0.52 \\
1.3 \\
1.3 \\
1.0\end{array}$ \\
\hline
\end{tabular}


groups is that frequent blood transfusions have been made before the start of the routine screening tests (13). As well as unsafe transfusions, invasive procedures such as birth, circumcision and dental practices with non-sterile devices can be attributed to increased HCV seroprevalence in elderly. Distribution of anti-HCV positivity and age groups shown in studies conducted in Turkey is given in Table 2.

$\mathrm{HCV}$ seroprevalence in the world is increasing substantially with age. In addition, the prevalence of $\mathrm{HCV}$ in the world is peaking usually and mostly in the 55-64 age group according to the global data (26).

CDC recommendation for one-time testing for HCV in people born during 1945-1965 depends on the following facts: 1) HCV infection is affecting large number of population and can be diagnosed before the symptoms appear; 2) Testing for anti-HCV antibodies are now minimally invasive, and reliable; 3) Early diagnosis can facilitate early access to the treatment limiting the progression of the disease and can save significant life years; 4) Determination of unrecognized infections can limit transmissions; and 5) Testing is cost-effective (14). In this study, we also determined that anti-HCV seroprevalence in those aged 50 years and over was approximately 5 times higher than in people of other age groups (except for the 40-49 ages group). People living in high HCV prevalence areas or people having a history of HCV risk exposure/behaviour are recommended to take HCV serology testing according to data from the $\mathrm{WHO}$ (27).

In this study, we also found that the anti-HCV positivity rate increases with age as indicated in the literature. The highest rate of anti-HCV is observed as $2.1 \%$ in people aged 50 years and over. Overall anti-HCV positivity rate for all age groups is $1.1 \%$. According to data from this study together with $\mathrm{WHO}$ and $\mathrm{CDC}$ suggestions, we believe that it is appropriate to offer at least once anti-HCV serology testing for people over 50 years of age in whom the anti$\mathrm{HCV}$ seroprevalence is relatively high.

Ethics Committee Approval: This study is a retrospective research article, Informed Consent: Not needed, Concept: Özlem Aydemir, Tayfur Demiray, Mehmet Köroğlu, Design: Mustafa Altındiş, Ahmet Özbek, Data Collection or Processing: Özlem Aydemir, Tayfur Demiray, Mehmet Köroğlu, Analysis or Interpretation: Ihsan Hakkı Çiftçi, Literature Search: Özlem Aydemir, Tayfur Demiray, Mehmet Köroğlu, Writing: Özlem Aydemir, Tayfur Demiray, Mehmet Köroğlu, Peer-review: External and Internal peer-reviewed, Conflict of Interest: No conflict of interest was declared by the authors, Financial Disclosure: The authors declared that this study has received no financial support.

\section{References}

1. Kaya S. Kan donörlerinde hepatit B virusu, hepatit $C$ virusu ve insan immun yetmezlik virusuinfeksiyonu ve siŞlis sıklığı. Klimik Dergisi. 2008; 21: 65-68.

2. Gower E, Estes C, Blach S, Razavi-Shearer K, Razavi H. Global epidemiology and genotype distribution of the hepatitis $C$ virus infection. J Hepatol. 2014; 61(1 Suppl):45-57.

3. Ulutürk R. Kan donörlerinde yapılan rutin tarama testlerinin onbir yıllık değerlendirmesi. Turk Mikrobiyol Cem Derg. 2010; 40: $41-47$
4. Tabak F, Tosun S. Viral Hepatit Kitabı,7 baskı, Istanbul tıp kitabevi, 2013

5. Altindis M, T Demiray, M Köroğlu, A R Atasoy, R Kesli, S Tosun, M Ozdemir, A Aksozek, G Ece, Y Cetinkol, H Guducuoglu. Adultsbornbetween 1945 and 1965 in Turkey might need one time hepatitis $\mathrm{C}$ testing (MulticenterStudy). Pp.639. The 6thEurasiaCongress of InfectiousDiseases, 24-27 September, Belgrad, Serbia, (EACID-2014).

6. Mohd HK, Groeger J, Flaxman AD, Wiersma ST. Global epidemiology of hepatitis C virus infection: new estimates of age-specific antibody to HCV seroprevalence. Hepatology. 2013; 57: 1333-1342.

7. WHO, http://www.who.int/csr/disease/hepatitis/whocdscsrlyo 2003/en/index4.html (Accessed 03.04.2015)

8. Kara IH. Akut viral hepatit C. Turk Aile Hek Derg. 2008; 12: 84-94.

9. Tozun N, Özdoğan OC, Çakaloğlu Y, Idilman R, Karasu Z, Akarca UZ, Kaymakoğlu. A nationwideprevalencestudyand risk factorsforhepatitis A, B,C and D infections in Turkey. Hepatology. 2010; 52: 697

10. Karaca C, Cakaloğlu Y, Demir K, Ozdil S, Kaymakoğlu S, Badur S, Okten A. Risk Factors for the transmission of hepatitis $C$ virus infection in the Turkish population. Dig Dis Sc. 2006; 51: 365-369.

11. Kandemir Ö, Göksu M, Kurt Ö. Mersin ili kentsel bölge ve kent merkezine bağlı belde-köy sağlık ocağı bölgesinde hepatit $B$ ve C sıklığı. Viral Hepatit Derg. 2011; 17: 74-83

12. Yildirim M, Cakir S, Geyık MF, Ozdemir D, Güçlü E, Çakir M. Seroprevalences and associated risk factors of hepatitis B and C in adults. Turk J Med Sci. 2014; 44: 824-831.

13. Asan A, Akbulut A, Saçar S, Turgut H. Tunceli Devlet Hastanesine Başvuran Kişilerde HBsAg ve Anti-HCV Seroprevalansının Değerlendirilmesi.Viral Hepatit Derg. 2011; 17: 52-56.

14. CDC reports. http://www.cdc.gov/mmwr/pdf/rr/rr6104.pdf (acessed: 03.04.2015)

15. Demiraslan H, Aksöz S, Çitil BE. Adıyamanda'ki öğrencilerde HBsAg ve anti HCV seropozitifliği. Viral Hepatit Derg. 2008; 3:103-105.

16. Kurt H, Battal I, Memikoğlu O, Yeşilkaya A, Tekeli E. Ankara bölgesinde sağlıklı bireylerde HAV, HBV, HCV seropozitifliğinin yaş ve cinsiyete göre dağılımı. Viral Hepatit Derg. 2013; 8:88-96.

17. Kaçmaz B. Ankara ilinde hepatit $B$ ve hepatit $C$ infeksiyonuprevalansı. Viral Hepatit Derg. 2003; 8:97-101.

18. Ceylan A, Saka G, Acemoğlu H, Öztekinci T, Gül K. Diyarbakır'da çocukluk çağında hepatit C seroprevalansı. Viral Hepatit Derg. 2002; 8:536.

19. Yarar C, Bor Ö, Us T, Akgün Y, Akgün NA. Çok Sayıda Transfüzyon Alan Cocuklar ile Sağlıklı Cocuklarda TT Virus-DNA Varlığının Araştırılması. Mikrobiyol Bul. 2005; 39: 63-71.

20. Çoban M, Turhan V. Genç erişkinlerde HBsAg, anti HBs ve anti-HCV seroprevalansı. Türkiye EKMUD kongresi, 9-12 Mayıs Istanbul, 2012, s. 2247.

21. Akman SA, Köse Ş, Gözaydın A, Kertiş G, Atilla D. Yetiştirme yurdunda barınan cocuklarda hepatit $B$ ve hepatit $C$ prevalansı. IX. Ulusal Viral Hepatit Kongresi, 3-6 Nisan Antalya, 2008, s. 211.

22. Tekeroğlu MS, Aktaş E, Özerol IH, Durmaz R. 18-45 yaş kadınlarda HBsAg, anti-HCV ve anti-HIV seropozitifliği. Viral Hepatit Derg. 2004; 9: 46-49.

23. Çetinkol Y, Altınçekiç Yıldııı A. Sağlık meslek lisesi öğrencilerinde HBsAg, anti-HBs, anti-HCV ve anti-HAV IgG sonuçlarının değerlendirilmesi. Viral Hepatit Derg. 2012; 18: 23-25.

24. Günal Ö, Barut HŞ, Cihan Çekiç Ç, Erkorkmaz Ü, Yıldız F, Göral $A$. Tokat bölgesi çocuk yaş grubunda hepatit $B$ ve hepatit $C$ virüs prevalansı. X. Ulusal Viral Hepatit Kongresi, 1-4 Nisan Antalya, 2010, s. 107.

25. Gürbüz Y, Tosun S, Balık | ve ark. Ülkemizde HBV ve HCV seroprevalansı değișiyor mu? 2008 yılı verileri. X. Ulusal Viral Hepatit Kongresi, 1-4 Nisan Antalya, 2010, s.107.

26. WHO, http://www.who.int/csr/disease/hepatitis/whocdscsrlyo 2003/en/index4.html (Accessed 03.06.2015)

27. WHO, http://www.who.int/mediacentre/factsheets/fs164/en/ (Accessed:03.06.2015) 